\title{
THE INFLUENCE OF CORPORATE FINANCIALIZATION ON ASYMMETRIC COST BEHAVIOR: WEAKENING OR WORSENING
}

\author{
Guanping $\mathrm{ZHU}^{1}$, Wenxiu $\mathrm{HU}^{1}$, Tao $\mathrm{PENG}^{2}$, Chaokai XUE ${ }^{3}$ \\ ${ }^{1}$ School of Economics and Management, Xian University of Technology, Xian, China \\ ${ }^{2}$ International School of Business \& Finance, Sun Yat-sen University, Zhuhai, China \\ ${ }^{3}$ School of Business, Shandong University of Technology, Zibo, China
}

Received 06 August 2019; accepted 05 August 2020

\begin{abstract}
This paper investigates the relationship between corporate financialization and asymmetric cost behavior using the Chinese listed companies over the period of 2009-2017. To examine the heterogeneous impacts of corporate financialization on asymmetric cost behavior, the paper analyzes the subsamples classified by different internal controls, compensation incentives, and agency problems. The multiple linear regression is used to test the research hypothesis. The research finds a negative relationship between corporate financialization and asymmetric cost behavior, which indicates that corporate financialization significantly weakens asymmetric cost behavior. Further studies show that the negative effect of corporate financialization on asymmetric cost behavior is mainly manifested in firms with good internal control quality, strong compensation incentive and low agency problem. On the contrary, the negative effect is insignificant in firms with poor internal control quality, weak compensation incentive and high agency problem. The results can not only enrich the existing literature, but also provide new evidence and inspiration for how to control asymmetric cost behavior of enterprises.
\end{abstract}

Keywords: corporate financialization, asymmetric cost behavior, heterogeneous impacts, multiple linear regression, internal control, compensation incentive, agency problem.

JEL Classification: D22, D23, G32, M21, M41.

\section{Introduction}

In recent years, more and more attention from the real sectors and scholars has been paid to the corporate financialization. Corporate financialization, as a derivative of the economic financialization, refers to the phenomenon that non-financial enterprises allocate capital into financial assets of high virtualization through financial channel (Demir, 2009), such as tradable financial assets, stocks, bonds and so on. It is the subdivision and deepening of

\footnotetext{
*Corresponding author. E-mail: pengt28@mail.sysu.edu.cn
} 
economic financialization from macro economy to micro economy. Although there are many reasons for corporate financialization, such as the agency behavior of managers, the change of corporate governance structure and the higher expected return of financial assets, the main root lies in the recession of entity economy and the decline of earnings ability (Froud et al., 2000; Du et al., 2017).

At present, scholars generally believe that corporate financialization has Crowding Out Effect. As documented, corporate financialization could squeeze out physical investment and thus show negative effects. For example, corporate financialization will result in the insufficiency of innovative investment (Seo et al., 2012), the decrease of physical investment (Akkemik \& Ozen, 2014; Tori \& Onaran, 2018), the crash of stock price (Peng et al., 2018), the decline of future performance (Du et al., 2017) and so on. According to the agency theory, under information asymmetry and managerial entrenchment, managers make investment decisions to maximize their own benefits (rather than the benefits of corporate shareholders) so as to increase on-the-job consumption and build managers' empire through the misallocation of corporate resources, especially in unstable and uncertain environment (Jensen \& Meckling, 1976; Jensen, 1986; Chen et al., 2012).

Given the previous studies, does corporate financialization have a worse impact on the asymmetric cost behavior in a less developed market? If so, this paper further examines whether the corporate governance mechanisms, especially the internal control, compensation incentive and agency problem, also affect the relationship between corporate financialization and asymmetric cost behavior. The answers to these questions are not only helpful for enterprises to understand the economic consequences of corporate financialization on asymmetric cost behavior, but also provide a solid theoretical sustenance for the government to establish economic policies.

In order to answer the two questions, the paper examines whether corporate financialization affects asymmetric cost behavior, using a sample of 18349 observations from the Chinese listed companies during 2009-2017. It is worthwhile that the time-span ranging from 2009 to 2017 enables to include the GEM (Growth Enterprises Market) listed companies and avoid the potential impact of the 2008 Global Financial Crisis. Firstly, the linear test shows a direct relationship between corporate financialization and asymmetric cost behavior. Secondly, to mitigate other factors' effects on the asymmetric cost behavior, the paper further tests the relationship by quantile regression, endogeneity tests and other robustness checks. Finally, in order to explore the heterogeneous impacts of corporate financialization on asymmetric cost behavior, three moderator variables (internal control, compensation incentive and agency problem) are further introduced to the regression model.

This research contributes to the literature in the following ways. First, this study is the first to examine the relationship between corporate financialization and asymmetric cost behavior. Although prior research has identified a set of corporate determinants to asymmetric cost behavior, such as managerial expectations (Banker \& Byzalov, 2014; Salehi et al., 2018), adjustment costs (Calleja et al., 2006; Cannon, 2014; Banker et al., 2013), agency problems (Jensen \& Meckling, 1976; Balakrishnan et al., 2014; Priantana et al., 2020), corporate social responsibility (Habib \& Hasan, 2019), corporate internal control (Kim et al., 2019), corporate strategy (Zhou et al., 2016), community social capital (Hart- 
lieb et al., 2020), financing constraints (Jiang et al., 2015), etc. However, few research has investigated whether the financial behavior of enterprises could affect asymmetric cost behavior. From this perspective, this paper enriches the literature on the determinants of asymmetric cost behavior.

Second, this paper also extends the research by analyzing the different aspects of corporate governance. Prior research has showed that when there are defectives in internal control and lack of external incentive constraints in the enterprises, there is a great possibility for the managers to make self-interested decisions (Morse et al., 2011; Chen et al., 2012; Bugeja et al., 2015; Kim et al., 2019), which indicates that the influence of corporate financialization on asymmetric cost behavior may be potentially affected by internal supervision, external incentive and managers' agency behavior. In order to explore whether this influence varied with corporate governance of enterprises, this paper also discussed the relationship from three perspectives (internal control, compensation incentive and agency problem) for the first time, and provided new evidence on how to control asymmetric cost behavior of enterprises.

The remaining of this paper is arranged as follows. Section 1 introduces literature review. Section 2 presents the theoretical analysis and research hypothesis. Section 3 describes the data source and research design. Section 4 reports the empirical results. Section 5 explains the robustness checks. Section 6 provides the heterogeneous impacts analysis. The last section concludes.

\section{Literature review}

\subsection{Asymmetric cost behavior}

Asymmetric cost behavior is also called cost stickiness. According to the traditional cost theory, there is a linear relationship between sales cost and sales revenue (Noreen, 1991). Specifically, the cost change caused by the increase or decrease of sales volume is symmetrical. However, recent research finds that the cost change caused by the increase of sales is larger than that caused by the decrease of sales, implying the existence of asymmetric cost behavior (Anderson et al., 2003). Costs are naturally generated in resource allocation, asset use and consumption. The short-term asymmetric cost behavior will reduce business efficiency as well as increase the operating risk. However, the long-term asymmetric cost behavior will damage the sustainable development of enterprises (Balakrishnan et al., 2014; Guenther et al., 2014).

Nowadays, there have been many discussions on the determinants of asymmetric cost behavior. Previous studies have consistently agreed that managerial expectations, adjustment costs, and agency problems are the main influence factors of asymmetric cost behavior. Managerial expectation theory demonstrates that managers with optimistic expectations for future sales tend to increase cost stickiness, while managers with pessimistic expectations tend to reduce it (Banker \& Byzalov, 2014; Salehi et al., 2018). The adjustment cost view deems that enterprises tend to keep the cost stickiness because the adjustments of corporate operating decisions usually come along with the great enhancement of the cost 
(Calleja et al., 2006; Cannon, 2014; Banker et al., 2013). The agency theory holds that due to the agency conflict between managers and shareholders, the enterprises with high agency problem are more inclined to have cost stickiness (Jensen \& Meckling, 1976; Balakrishnan et al., 2014; Priantana et al., 2020). Chen, Lu and Sougiannis (2012) also found that managers with empire-building intention tend to expand the size of the business when the sale increases, and to avoid shrinking corporate resources when the sale decreases, which will result in the deviation of the enterprises' cost from the optimal level of resource allocation and the formation of asymmetric cost behavior.

However, there are some scholars insisting that other factors have more explanatory power for asymmetric cost behavior, such as socio-political factors (Prabowo et al., 2018), political uncertainty (Lee et al., 2020), tax rate cuts (Haga et al., 2019), corporate social responsibility (Habib \& Hasan, 2019), corporate internal control (Kim et al., 2019), corporate strategy (Zhou et al., 2016), community social capital (Hartlieb et al., 2020), financing constraints (Jiang et al., 2015), managerial overconfidence (Heidari, 2014), managerial incentives (Kama \& Weiss, 2013), etc.

Overall, although many scholars have discussed the determinants of asymmetric cost behavior from the national, corporate, and manager levels respectively, few research has examined the influence of corporate financial behavior (corporate financialization) on asymmetric cost behavior. Therefore, clarifying whether corporate financialization is the determinants of asymmetric cost behavior is of great theoretical and practical significance.

\subsection{Corporate financialization}

At present, corporate financialization has attracted much attention of academia. Scholars have made important research progress on corporate financialization. Most of these studies focused on the triggering factors and economic consequences of corporate financialization.

A large number of previous studies found that the triggering factors for corporate financialization are the higher expected return of financial assets, the excessive supply of financial assets and the physical intermediaries. Demir (2009) pointed out that corporate portfolio investment is no longer a reserve of excess liquidity, and the fundamental reason for promoting corporate financialization is the decline of real economic profits. Driven by capital profits, the enterprises are more inclined to invest their cash resources into short-term financial assets which are characterized with the high earnings as well as quick return, rather than in irreversible long-term fixed projects. Zhang and Sun (2014) used Chinese manufacturing listed companies as a sample, and found that the main source of corporate financialization is the excess supply of financial resources, which leads a large number of financial assets to the real estate market, resulting in the bubbles in the assets price and speculation prevalence. Shin and Zhao (2013) argued that the factor which promotes corporate financialization is the physical intermediaries. Many companies are not entitled for the credit financing from the banks, so those qualified ones will get a large amount of money from the banks and then lend it to those unqualified entities enterprises through corporate financialization.

The economic consequences of corporate financialization mainly refer to the restraint on the corporate innovation, the decline of physical investment, the descend of future perfor- 
mance, etc. Seo, Kim and Kim (2012) investigated the influence of corporate financialization on R\&D investment, and found that corporate financialization inhibited the corporate innovation, and the degree of inhibition varies in different sizes and compensation incentives. Tori and Onaran (2018) analyzed the panel data of Western European countries, and concluded that the financialization of non-financial listed companies resulted in lower physical investment, which showed a significant Crowding Out Effect. Du, Zhang, and Chen (2017) found that corporate financialization could damage the future operating performance of real enterprises based on the data of Chinese listed companies from 2008 to 2014. It indicates that the Reservoir Effect of corporate financialization is weaker than the Crowding Out Effect, which is more pronounced in weak financial ecosystems and state-owned enterprises.

Building upon the prior studies, although scholars have accomplished many jobs on the relationship between corporate financialization and asymmetric cost behavior, there is little literature studying the relationship between corporate financialization and asymmetric cost behavior. In order to make up for the current research vacancy, this paper intends to further take Chinese listed companies as a sample to investigate the influence of corporate financialization on asymmetric cost behavior and its related mechanisms.

\section{Theoretical analysis and research hypothesis}

\subsection{The direct influence of corporate financialization on asymmetric cost behavior}

The Reservoir Effect refers to the situation when a company is out of cash, it can realize capital turnover by selling financial assets, which helps to reduce the dependence on external financing (Gehringer, 2013; Du et al., 2017). However, this Reservoir Effect is mainly reflected in tradable financial assets investment (Huang et al., 2018). As enterprises hold more and more non-tradable financial assets (e.g., real estate investment), there will be more and more financing constraints for them (Du et al., 2017). Meanwhile, if the enterprises want to keep excessively redundant resources, the ascending financing constraints will confront them with higher opportunity costs and larger financial risks (Jiang et al., 2015). Therefore, the enterprises with high financing costs will tend to reduce redundant resources when sales decline, thereby weakening the asymmetric cost behavior.

The precautionary saving theory also believes that, in order to reduce the adverse impact of the future break of the capital chain on enterprises and meet the needs of future production and operation, as well as to pursue the high returns on financial assets, managers have the incentives to reasonably allocate the financial assets across periods (Theurillat et al., 2010; Duchin et al., 2017). As a result, the corporate financialization can help to reduce their current free cash flow. The reduction in free cash flow will further weaken managerial motivation to build managers' empire (Jensen \& Meckling, 1976; Chen et al., 2012), which is beneficial to curb the managers' excessive expansion of production capacity when the corporate sale rises and increase the dispose of redundant resources when it declines (Kama \& Weiss, 2013).

At the same time, although the corporate investment in short-term financial assets helps to reduce the financial distress and operating risk, the investment of the long-term 
financial assets like stock and real estate investments will make the enterprises more opt for getting involved in financial distress and bankruptcy (Zhang \& Sun, 2014). The increasing of bankruptcy risk will enable managers to take the balance of sales revenue and expenditure into account while pursuing corporate financialization (Sung et al., 2017), thereby weakening the asymmetric cost behavior.

Moreover, the transfer effect of $\mathrm{R} \& \mathrm{D}$ investment can also indirectly testify that corporate financialization is conducive to alleviate asymmetric cost behavior of the corporate. Specifically, in the case of limited resources, the more financial assets are invested, the lower physical investments there will be (Orhangazi, 2008). This shows that, to some extent, the higher the degree of corporate financialization is, the more significant the Crowding Out Effect of R\&D innovation investment is (Seo et al., 2012). The more resources companies invest in $\mathrm{R} \& \mathrm{D}$ innovation, the greater the cost stickiness of the enterprises is (Venieris et al., 2015). Because of the uncertainty of innovation output, the resources need to be invested in the long term and cannot be cut down. Consequently, corporate financialization may also weaken the asymmetric cost behavior of enterprises by squeezing out R\&D investment.

Building on the analysis from prior research, the paper assumes that the corporate financialization is negatively associated with the asymmetric cost behavior.

H1: The corporate financialization can significantly weaken the asymmetric cost behavior.

\subsection{The scenario analysis of corporate financialization on asymmetric cost behavior}

$\mathrm{H} 1$ indicates that corporate financialization helps to mitigate asymmetric cost behavior of enterprises. It is also important to find out whether such influential relationship exists in different scenes. Prior research shows that when the companies are in lack of external incentives and have defectives in internal control, it is more probable for the managers to make self-interested decisions (Morse et al., 2011; Chen et al., 2012; Bugeja et al., 2015; Kim et al., 2019). For example, to build managers' empire or increase on-the-job consumption, managers tend to retain excessively redundant resources even when the sale declines, which shows that the influence of corporate financialization on asymmetric cost behavior may be potentially affected by internal supervision, external incentive and managers' agency behavior. Therefore, in order to obtain more valuable research conclusions, this paper takes a further look into the heterogeneous effects of internal supervisions, external incentives and agency problems. This article will focus on the scenario analysis from three perspectives (internal control, compensation incentive and agency problem).

\section{1) the role of internal control}

Internal control, as an organizational rule and procedure for protecting enterprise assets and detecting fraud, waste and abuse (Park et al., 2017), is an important part of enterprises' risk operation and management. Good internal control quality can not only effectively restrain the managers' behaviors like moral hazard (Holmstrom, 1979), adverse selection (Akerlof, 1978), managerial entrenchment and the invasion of the interests of 
small stockholders (Jensen \& Meckling, 1976), but also can enhance the enterprises' ability to make the right cost and investment decisions, and ultimately improve the efficiency and effectiveness of operation. However, poor internal control quality will not only result in the lack of effective monitoring of their business and management activities (Hadi et al., 2018), which will make financial assets investment deviate from corporate value, but also cause confusion in cost management, thereby leading to the increase of operating risk and the deviation of strategic objectives.

According to the following analysis, this article proposes that the impact of corporate financialization on asymmetric cost behavior may show significant differences under different quality of internal control.

Firstly, good internal control quality can effectively reduce managers' agency problem. A weak agency behavior can not only prevent managers from the immoral actions and adverse selection (Holmstrom, 1979; Akerlof, 1978), encourage managers to invest in financial assets when they have slack cash as well as maintain a good balance of risks and benefits in both financial assets and physical investments, but also restrain their motivation of empire-building (Jensen \& Meckling, 1976; Chen et al., 2012), helping to reduce the retention of excess resources in response to demand declines. Secondly, the enterprises with good internal control quality can effectively restrain the real earnings manipulation of the enterprises and help to improve the quality of earnings information in the financial report of the enterprises, which will inhibit the manipulation behavior of sales products, production costs and discretionary costs (Chen et al., 2019). The managers' impetus to maximize the shareholders' value and the reduction of manipulation behavior will in turn lead to more corporate financialization and cost optimization. Finally, the corporate, business and functional strategy (e.g., investment and the cost minimization strategy) in the companies with good internal control quality can be implemented step by step (Hunziker, 2017). Meanwhile, the disclosure of the financial statements and the use of financial resources are also more effective (Park et al., 2017).

In contrast, the enterprises with the poor internal control quality not only lack the incentive mechanisms to managers, which will result in the decreasing of managers' tendency to invest financial assets, but also may lead to wrong internal financial reports. The distortion of internal financial reports probably make the management ineffective in product and cost forecasting, lead to chaotic cost control and sales management, and ultimately decrease efficiency of cost management (Cheng et al., 2018; Hadi et al., 2018). To some extent, this will distort the effect of corporate financialization on asymmetric cost behavior. Thus, this paper predicts that the effect of corporate financialization on asymmetric cost behavior is more pronounced when firms have good internal control quality. Therefore, the paper proposes the following hypothesis.

H2: The effect of corporate financialization on asymmetric cost behavior is more pronounced in firms with good internal control quality.

\section{2) the role of compensation incentive}

In the past few decades, scholars in the field of compensation incentive generally believe that, in order to improve the future operating performance, the enterprises should promote the incentive mechanisms for the managers, such as high management stock op- 
tions, restricted stock and dividend plans. An effective compensation system can alleviate agency problem and establish a psychological contract with managers, and then impel managers to make managerial decisions which are beneficial to shareholders as well as conducive to the company development (Chen et al., 2012). For example, managers will rationally hold financial assets and optimize asymmetric cost behavior. On the contrary, the ineffective compensation incentive system will weaken their enthusiasms as well as their efforts for work, reduce their interest in financial investment and the management of asymmetric cost behavior, therefore inducing the excessive pursuit of on-the-job consumption and the decline of corporate performance (Jensen \& Murphy, 1990; Steinbach et al., 2017).

According to the following analysis, the paper proposes that the impact of corporate financialization on asymmetric cost behavior may show significant differences under different compensation incentives.

On one hand, stronger compensation incentive will stimulate managers to invest financial assets and optimize asymmetric cost behavior. Compared with entities investment, financial assets investment will be bestowed with excessive return, especially the investments in real estate and stock market (Du et al., 2017). Besides, the rapid return of financial investment is conducive to the quick improvement of managers' reputation, which can not only increase the managers' future salary and benefits, but also consolidate the managers' present position in the company, then stimulating them to increase corporate financialization. However, due to the temptation of high salary in the future and the risks caused by the difficulty of restarting their posts after being dismissed, managers will also take the balance of revenue and expenditure of the enterprises into the account, the cost control and the efficiency of sales and operation while pursuing corporate financialization (Sung et al., 2017). On the other hand, the compensation incentive is also a strong corporate governance mechanism, which can reduce agency problem and alleviate the managers' rent-seeking behavior (Datta et al., 2009). For example, managers will restrain their motives to build a managerial empire, and the restraint will encourage managers to appropriately increase the holding of financial assets when slack resources are abundant and reduce redundant resources during the sales-decline periods (Chen et al., 2012).

Conversely, in the enterprises with weak compensation incentive, the inefficient resources allocation could occur during financial assets investment, cost control and product sale owing to managers' excessive pursuit of stable life and on-the-job consumption ( $\mathrm{Li}$ et al., 2015). This may lead to a weaker impact of corporate financialization on asymmetric cost behavior. The above studies show that the enterprises with strong compensation incentive create a good business environment, which will be favorable for the effect of corporate financialization on asymmetric cost behavior. Therefore, the third hypothesis is proposed as follows.

H3: The effect of corporate financialization on asymmetric cost behavior is more pronounced in firms with stronger compensation incentive.

\section{3) the role of agency problem}

Since the view about separating the ownership and the management emerges, agency problem has never been out of the attention of academic world, and has become the research focus of corporate governance. Agency theory believes that, considering the human 
capital specificity, the high conversion cost and the reputation damage after being fired, managers with higher agency problem often choose to conduct some kind of behavior that is beneficial to consolidate their position and maximize their own benefits, such as misallocating corporate resources (e.g., short-sighted and rip-off investments) and excessively controlling corporate resources when sales declines (Jensen \& Meckling, 1976; Chen et al., 2012; Krause et al., 2014; Aktas et al., 2019).

According to the following analysis, the article proposes that the impact of corporate financialization on asymmetric cost behavior may show significant differences under different agency problems.

Firstly, if the managers' agency problem is low, their motivation to build managers' empire will become weaker (Jensen, 1986). The weaker the motivation is, the more likely they will follow the decisions in favor of the interests of the firm's shareholders rather than that of their own (Hou et al., 2017). For example, they will properly increase the financial assets holdings and reduce the control of redundant resources when sales decrease. Secondly, the enterprises with low agency problem are often equipped with better internal and external regulators like corporate governance and audit committees (Xie et al., 2003; Chen et al., 2012). This is beneficial for the enterprises to invest appropriately in financial assets and keep the equilibrium relationship between costs and sales. When this advantage is manifested in asymmetric cost behavior, it can prevent managers from adding SG\&A (selling, general and administrative) costs too much in response to demand increases, and encourage them to eliminate slack resources in response to demand decreases.

Conversely, when the agency problem of enterprises is high, managers are more inclined to pursue on-the-job consumption and maximize their own benefits through the misallocation of corporate resources (Krause et al., 2014; Aktas et al., 2019), which will neglect the management of financial assets and asymmetric cost behavior. Furthermore, the enterprises with high agency problem are often accompanied by deficiencies in the management system, such as the shortage of payment incentives (Sung et al., 2017), the defect of internal control (Cheng et al., 2018), the concealment of adverse information, the reduction of voluntary information disclosure (Ang et al., 2000), etc. Building upon the theoretic and empirical evidence, this paper predicts a stronger negative effect of corporate financialization on asymmetric cost behavior in firms with low agency problem. Therefore, here comes the last hypotheses.

H4: The effect of corporate financialization on asymmetric cost behavior is more pronounced in firms with low agency problem.

\section{Model design and sample selection}

\subsection{Model design}

In order to measure the direct influence and heterogeneous impacts of corporate financialization on asymmetric cost behavior, this paper relies on the model (1) which is based on the approach developed by Anderson et al. (Anderson et al., 2003) and extended by other scholars (Venieris et al., 2015; Zhou et al., 2016; Salehi et al., 2018). 


$$
\begin{aligned}
& \operatorname{In}\left(\text { Costs }_{i t} / \text { Costs }_{i t-1}\right)=\beta_{0}+\beta_{1} \operatorname{In}\left(\text { Sales }_{i t} / \text { Sales }_{i t-1}\right)+\beta_{2} D D \times \operatorname{In}\left(\text { Sales }_{i t} / \text { Sales }_{i t-1}\right)+ \\
& \beta_{3} D D \times \operatorname{In}\left(\text { Sales }_{i t} / \text { Sales }_{i t-1}\right) \times \text { Fin }_{i t}+ \\
& \beta_{4} D D \times \operatorname{In}\left(\text { Sales }_{i t} / \text { Sales }_{i t-1}\right) \times \operatorname{InAS}_{i t}+ \\
& \beta_{5} D D \times \operatorname{In}\left(\text { Sales }_{i t} / \text { Sales }_{i t-1}\right) \times \operatorname{InES}_{i t}+ \\
& \beta_{6} D D \times \operatorname{In}\left(\text { Sales }_{i t} / \text { Sales }_{i t-1}\right) \times G D P_{i t}+ \\
& \beta_{7} D D \times \operatorname{In}\left(\text { Sales }_{i t} / \text { Sales }_{i t-1}\right) \times \text { Suc }_{i t}+ \\
& \text { Industry }+ \text { Year }+\varepsilon_{i t} \text {. }
\end{aligned}
$$

Where In $\left(\right.$ Costs $_{i t} /$ Costs $\left._{i t-1}\right)$ represents the log transformation of the change in sales costs for firm $i$ from year $t$ to $t-1$. In $\left(\right.$ Sales $_{i t} /$ Sales $\left._{i t-1}\right)$ denotes the log transformation of the change in sales revenue. $D D$ is the dummy variable of the decline of sales revenue. When the sales revenue of the current period is less than the previous sales revenue, the value is 1 , otherwise it is 0 . Fin is a proxy of corporate financialization and was measured as financial assets divided by total assets (Du et al., 2017). Financial assets include tradable financial assets, net loans and advances, net financial assets available for sale, net investments held to maturity, net derivative financial assets and net investment real estate. InAS describes the capital intensity and was measured as the log transformation of the total assets divided by sales revenue. InES is the employee intensity and was measured as the $\log$ transformation of employee size divided by sales revenue. GDP is the Gross Domestic Product and was measured by the growth rate of GDP. Suc is a dummy variable and was measured by whether the annual sales revenue has declined for two consecutive years. When the sales revenue has fallen for two consecutive years, the value is 1 , otherwise 0 . $\beta_{i}$ is the parameter to be estimated. Industry and Year are industrial and time fixed effects respectively. $\varepsilon$ is the error term.

In formula (1), the coefficient $\beta_{1}$ measures the percentage increase in sales costs for a $1 \%$ increase in sales revenue. The sum of the coefficients $\left(\beta_{1}+\beta_{2}\right)$ measures the percentage decrease in sales costs for $1 \%$ decrease in sales revenue. According to the definition of asymmetric cost behavior, when the marginal increment $\beta_{1}$ is larger than the marginal reduction $\left(\beta_{1}+\beta_{2}\right)$, the asymmetric cost behavior happens in the enterprises (Venieris et al., 2015). The greater the difference between the marginal increment and the marginal reduction is, the stronger the asymmetric cost behavior of enterprises is. In other words, if there is asymmetric cost behavior in an enterprise, $\beta_{2}$ must be negative and significant. Furthermore, the smaller $\beta_{2}$ is, the more serious the asymmetric cost behavior is.

This paper mainly pays attention to the coefficient $\beta_{3}$, which measures the influence of corporate financialization on asymmetric cost behavior. If it is positive and significant, the results demonstrate the corporate financialization can weaken the asymmetric cost behavior of enterprises. On the Contrary, if it is negative and significant, the results indicate the corporate financialization will worsen the asymmetric cost behavior of enterprises. 


\subsection{Sample selection}

The sample in this paper is the A-share listed companies of Chinese Stock Exchanges market from the year 2009 to 2017. In addition, the sample data is screened according to the following criteria. First, the listed companies of the special treatment (ST) in financial statements are excluded in order to avoid extreme values effects. Second, the paper deletes financial listed companies since their financial statement are incompatible with those of other listed companies (Hartlieb et al., 2020). Third, observations with missing values and those with error information like listed companies with zero assets are excluded. Last, in order to satisfy the virtual variables that the sales revenue of enterprises should be kept falling for two consecutive years, the listed companies which haven't been on the market for at least continuous 3 years are also excluded (Calleja et al., 2006).

Through the above screening, the paper finally obtains 18349 annual observations from CSMAR (China Stock Market and Accounting Research) database, which provides the most complete financial information of listed companies in China. In order to avoid the possible error caused by abnormal values for the analysis results, all continuous variables are winsorized at $1 \%$ and $99 \%$ (Chen et al., 2012).

\section{Empirical results}

\subsection{Descriptive analysis}

Table 1 provides the descriptive statistics results in this paper. As shown in the line 2 of Table 1, the average change rate between the current sales cost and the previous sales cost is 1.215 , and the standard deviation is 0.525 . Meantime, the average change rate between the current sales revenue and the previous sales revenue is 1.232 , and the standard deviation is 0.637. The results show that the change rate of the sales cost and that of the sales revenue as

Table 1. Descriptive statistics results

\begin{tabular}{|l|c|c|c|c|c|}
\hline \multicolumn{1}{|c|}{ Variable } & Mean & Std & Min & Median & Max \\
\hline Costs $_{i t} /$ Costs $_{\text {it }-1}$ & 1.215 & 0.525 & 0.460 & 1.117 & 4.681 \\
\hline Sales $_{i t} /$ Sales $_{\text {it }-1}$ & 1.232 & 0.637 & 0.408 & 1.115 & 5.712 \\
\hline Fin & 0.033 & 0.067 & 0 & 0.006 & 0.390 \\
\hline DD & 0.282 & 0.450 & 0 & 0 & 1 \\
\hline Asset $_{i t} /$ Sales $_{i t}$ & 2.658 & 2.524 & 0.384 & 1.925 & 17.369 \\
\hline Employs $_{\text {it }}$ Sales $_{\text {it }}$ & 0.154 & 0.135 & 0.006 & 0.118 & 0.767 \\
\hline GDP & 0.106 & 0.036 & 0.069 & 0.101 & 0.184 \\
\hline Suc & 0.134 & 0.341 & 0 & 0 & 1 \\
\hline Internal control $^{\text {Compensation incentive }}$ & 0.733 & 0.442 & 0 & 1 & 1 \\
\hline Managerial expenses ratio & 0.450 & 0.132 & 0.216 & 0.431 & 0.870 \\
\hline
\end{tabular}

Note: The unit of sales revenue in capital intensity is 100,000 RMB. 
a whole goes in the same direction within the range of change. This is consistent with the previous findings. Corporate financialization $($ Mean $=0.033)$ shows the degree of corporate financialization is not very serious. However, the minimum value $(0)$ and the maximum (0.390) imply that there is a large gap among listed companies. The dummy variable of the decrease in sales revenue $($ Mean $=0.282)$ indicates that the overall sales revenue of most Chinese listed companies showed an upward trend during 2009-2017. The internal control $($ Mean $=0.733)$ shows that $73.3 \%$ of companies have been flawless in it. The compensation incentive $($ Mean $=0.450)$ indicates that the annual salary ratio of the top-three paid senior administrators (directors, supervisors and executives) is $45 \%$. The ratio of managerial expenses $($ Mean $=0.103)$ shows that the organizational and administrative costs has taken $10.3 \%$ of the company's profits. Finally, the results of capital intensity, employee intensity and the growth rate of GDP are also consistent with previous studies.

\subsection{Main results}

Table 2 reports the robust standard error regression results for the influence of corporate financialization on asymmetric cost behavior. As shown in the column 2 of Table 2, the coefficient of $\operatorname{In}\left(\right.$ Sales $_{i t} /$ Sales $\left._{i t-1}\right)$ is 0.872 and that of $D D \times \operatorname{In}\left(\right.$ Sales $_{i t} /$ Sales $\left._{i t-1}\right)$ is -0.056 , which are significant at the $1 \%$ level. These empirical results reveal that asymmetric cost behavior exists in Chinese listed companies, which is consistent with the prior studies. When the sales revenue increases by $1 \%$, the sales cost increases by $87.2 \%$. On the contrary, when the sales

Table 2. Main results

\begin{tabular}{|c|c|c|c|}
\hline Variable & Model 1 & Model 2 & Model 3 \\
\hline $\operatorname{In}\left(\right.$ Sales $_{i t} /$ Sales $\left._{i t-1}\right)$ & $\begin{array}{l}0.872^{* * *} \\
(138.69)\end{array}$ & $\begin{array}{l}0.867^{* * *} \\
(137.94)\end{array}$ & $\begin{array}{l}{ }_{0.866^{* * *}} \\
(137.83)\end{array}$ \\
\hline$D D \times \operatorname{In}\left(\right.$ Sales $_{i t} /$ Sales $\left._{i t-1}\right)$ & $\begin{array}{c}-0.056^{* * *} \\
(-4.23)\end{array}$ & $\begin{array}{c}-1.432^{* * *} \\
(-9.76)\end{array}$ & $\begin{array}{c}-1.399^{* * *} \\
(-9.47)\end{array}$ \\
\hline$D D \times \operatorname{In}\left(\right.$ Sales $_{i t} /$ Sales $\left._{i t-1}\right) \times$ Fin & - & - & $\begin{array}{c}0.483^{* * *} \\
(2.82)\end{array}$ \\
\hline$D D \times I n\left(\right.$ Sales $_{i t} /$ Sales $\left._{i t-1}\right) \times \operatorname{InAS}$ & - & $\begin{array}{c}-0.107^{* * *} \\
(-7.82)\end{array}$ & $\begin{array}{c}-0.111^{* * *} \\
(-8.10)\end{array}$ \\
\hline$D D \times I n\left(\right.$ Sales $_{i t} /$ Sales $\left._{i t-1}\right) \times \operatorname{InES}$ & - & $\begin{array}{c}-0.108^{* * \star} \\
(-10.39)\end{array}$ & $\begin{array}{l}-0.105^{* \star \star} \\
(-10.03)\end{array}$ \\
\hline$D D \times I n\left(\right.$ Sales $_{i t} /$ Sales $\left._{i t-1}\right) \times G D P$ & - & $\begin{array}{l}0.533 \\
(1.24)\end{array}$ & $\begin{array}{l}0.537 \\
(1.25)\end{array}$ \\
\hline$D D \times \operatorname{In}\left(\right.$ Sales $_{i t} /$ Sales $\left._{i t-1}\right) \times$ Suc & - & $\begin{array}{c}0.059^{* * *} \\
(2.89)\end{array}$ & $\begin{array}{c}0.058^{* * *} \\
(2.84)\end{array}$ \\
\hline Cons & $\begin{array}{l}0.001 \\
(0.13)\end{array}$ & $\begin{array}{l}0.001 \\
(0.05)\end{array}$ & $\begin{array}{l}0.001 \\
(0.03)\end{array}$ \\
\hline Industry/Year & Yes & Yes & Yes \\
\hline Obs & 18349 & 18349 & 18349 \\
\hline Adj. $R^{2}$ & 0.892 & 0.897 & 0.897 \\
\hline
\end{tabular}

Note: 1$)^{* * *},{ }^{* *},{ }^{*}$ denote significantly at $1 \%, 5 \%$ and $10 \%$ respectively. 2 ) The values reported in parentheses () indicate $t$ statistics. 
revenue decreases by $1 \%$, the sales cost only drops by $81.6 \%$. Column 4 of Table 2 describes the regression results that both control variables and the explanatory variable are included in the regression model. The coefficient of $D D \times \operatorname{In}\left(\right.$ Sales $_{i t} /$ Sales $\left._{i t-1}\right) \times$ Fin is positive $(0.483)$ and significant at the $1 \%$ level. This implies the corporate financialization can effectively weaken the asymmetric cost behavior, which means the higher the degree of corporate financialization is, the weaker the asymmetric cost behavior is.

\section{Robustness checks}

\subsection{Quantile regression}

Generally speaking, corporate financialization in the different quantile phases should exert different influences to the asymmetric cost behavior of enterprises. To examine whether there is a differential effect as well as to provide a robustness test for the research conclusion of this paper, the samples are divided by the quantile.

Table 3 presents the quantile regression results explaining the relationship between corporate financialization and asymmetric cost behavior. In column 2 to 5 , the coefficients of corporate financialization on asymmetric cost behavior are $1.031\left(10^{\text {th }}\right), 0.511\left(25^{\text {th }}\right), 0.481$ $\left(50^{\text {th }}\right)$ and $0.567\left(75^{\text {th }}\right)$ respectively, and are significant at the $1 \%$ level. These results indicate that the higher the corporate financialization is, the less pronounced the asymmetric cost behavior is.

Table 3. Quantile regression results

\begin{tabular}{|c|c|c|c|c|c|}
\hline Variable & Q10 & Q25 & Q50 & Q75 & Q90 \\
\hline In $\left(\right.$ Sales $_{i t} /$ Sales $\left._{i t-1}\right)$ & $\begin{array}{l}0.753^{* * *} \\
(66.89)\end{array}$ & $\begin{array}{c}0.891^{* * *} \\
(243.72)\end{array}$ & $\begin{array}{l}0.928^{* * *} \\
(247.36)\end{array}$ & $\begin{array}{l}0.966^{* * *} \\
(290.46)\end{array}$ & $\begin{array}{c}0.993^{* *} \\
(136.49)\end{array}$ \\
\hline$D D \times \operatorname{In}\left(\right.$ Sales $_{i t} /$ Sales $\left._{i t-1}\right)$ & $\begin{array}{c}-0.808^{* * *} \\
(-4.31)\end{array}$ & $\begin{array}{c}-0.879^{* * *} \\
(-6.84)\end{array}$ & $\begin{array}{c}-1.007^{* * *} \\
(-10.36)\end{array}$ & $\begin{array}{c}-1.148^{* * *} \\
(-7.14)\end{array}$ & $\begin{array}{c}-1.054^{* * *} \\
(-5.17)\end{array}$ \\
\hline$D D \times \operatorname{In}\left(\right.$ Sales $_{i t} /$ Sales $\left._{i t-1}\right) \times$ Fin & $\begin{array}{c}1.031^{* * *} \\
(4.04)\end{array}$ & $\begin{array}{c}0.511^{* * *} \\
(4.32)\end{array}$ & $\begin{array}{c}0.481^{* * *} \\
(5.06)\end{array}$ & $\begin{array}{c}0.567^{* * *} \\
(4.05)\end{array}$ & $\begin{array}{l}0.462 \\
(1.60)\end{array}$ \\
\hline$D D \times \operatorname{In}\left(\right.$ Sales $_{i t} /$ Sales $\left._{i t-1}\right) \times \operatorname{InAS}$ & $\begin{array}{l}-0.011 \\
(-0.67)\end{array}$ & $\begin{array}{c}-0.051^{* * *} \\
(-8.10)\end{array}$ & $\begin{array}{c}-0.052^{* * *} \\
(-4.98)\end{array}$ & $\begin{array}{c}-0.167^{* *} \\
(-14.47)\end{array}$ & $\begin{array}{l}-0.306^{* * *} \\
(-10.74)\end{array}$ \\
\hline$D D \times I n\left(\right.$ Sales $_{i t} /$ Sales $\left._{i t-1}\right) \times \operatorname{InES}$ & $\begin{array}{c}-0.068^{* * *} \\
(-4.93)\end{array}$ & $\begin{array}{c}-0.067^{* * *} \\
(-7.43)\end{array}$ & $\begin{array}{l}-0.071^{* * *} \\
(-10.78)\end{array}$ & $\begin{array}{c}-0.082^{* * *} \\
(-7.68)\end{array}$ & $\begin{array}{c}-0.076^{* * *} \\
(-5.58)\end{array}$ \\
\hline$D D \times I n\left(\right.$ Sales $_{i t} /$ Sales $\left._{i t-1}\right) \times G D P$ & $\begin{array}{c}1.215^{* * *} \\
(2.60)\end{array}$ & $\begin{array}{l}0.449^{*} \\
(1.73)\end{array}$ & $\begin{array}{l}0.489^{*} \\
(1.94)\end{array}$ & $\begin{array}{l}-0.526 \\
(-1.53)\end{array}$ & $\begin{array}{c}-1.127^{* *} \\
(-2.22)\end{array}$ \\
\hline$D D \times \operatorname{In}\left(\right.$ Sales $_{i t} /$ Sales $\left._{i t-1}\right) \times$ Suc & $\begin{array}{c}0.081^{* * *} \\
(2.94)\end{array}$ & $\begin{array}{l}0.032^{* *} \\
(2.55)\end{array}$ & $\begin{array}{l}0.013 \\
(0.89)\end{array}$ & $\begin{array}{l}0.033 \\
(1.63)\end{array}$ & $\begin{array}{c}0.094^{* * \star} \\
(2.95)\end{array}$ \\
\hline Cons & $\begin{array}{l}-0.032^{* * *} \\
(-19.69)\end{array}$ & $\begin{array}{c}-0.009^{* * \star} \\
(-18.05)\end{array}$ & $\begin{array}{l}0.009^{* * *} \\
(15.02)\end{array}$ & $\begin{array}{l}0.028^{* * *} \\
(36.32)\end{array}$ & $\begin{array}{l}0.061^{* * \star} \\
(36.55)\end{array}$ \\
\hline Industry/Year & Yes & Yes & Yes & Yes & Yes \\
\hline $\operatorname{Adj} . R^{2}$ & 0.668 & 0.708 & 0.735 & 0.752 & 0.768 \\
\hline
\end{tabular}

Note: 1$)^{* * *},{ }^{* *},{ }^{*}$ denote significantly at $1 \%, 5 \%$ and $10 \%$ respectively. 2 ) The values reported in parentheses () indicate t statistics. 


\subsection{Endogeneity tests}

This paper has demonstrated that the corporate financialization can help to reduce the asymmetric cost behavior of enterprises. However, the asymmetric cost behavior may keep steady in different time, implying it will remain unchanged in the short term. Besides, the enterprises with asymmetric cost behavior is likely to pursue the corporate financialization. Therefore, there may be some endogeneity problems like reverse causality in the results. In order to solve the problem, this paper chooses the data from the lagged one phase of corporate financialization to analyze. The regression results are presented in model 4 of Table 4 . This paper finds the coefficient of corporate financialization is significantly positive at the $5 \%$ level. Meanwhile, in order to eliminate the possible interference caused by other control variables, the analysis of all control variables is on the basis of the data of the lagged one phase. The regression results are presented in model 5 of Table 4 . The results show that the coefficient of corporate financialization is still significantly positive at the $5 \%$ level, indicating the corporate financialization can effectively weaken the asymmetric cost behavior.

Table 4. Results of endogeneity and other robustness tests

\begin{tabular}{|c|c|c|c|c|c|c|}
\hline Variable & Model 4 & Model 5 & Model 6 & Model 7 & Model 8 & Model 9 \\
\hline In $\left(\right.$ Sales $_{i t} /$ Sales $\left._{i t-1}\right)$ & $\begin{array}{l}0.865^{* * *} \\
(125.66)\end{array}$ & $\begin{array}{l}0.870^{* * *} \\
(126.34)\end{array}$ & $\begin{array}{l}0.867^{* * *} \\
(137.87)\end{array}$ & $\begin{array}{l}0.866^{* * *} \\
(137.77)\end{array}$ & $\begin{array}{l}0.856^{* * *} \\
(105.04)\end{array}$ & $\begin{array}{l}0.866^{* * *} \\
(131.45)\end{array}$ \\
\hline$D D \times I n\left(\right.$ Sales $_{i t} /$ Sales $\left._{i t-1}\right)$ & $\begin{array}{c}-1.476^{* * \star} \\
(-8.93)\end{array}$ & $\begin{array}{c}-0.625^{* * *} \\
(-4.87)\end{array}$ & $\begin{array}{l}-1.417^{* * *} \\
(-9.61)\end{array}$ & $\begin{array}{c}-1.399^{* * *} \\
(-9.47)\end{array}$ & $\begin{array}{c}-1.171^{* * *} \\
(-7.75)\end{array}$ & $\begin{array}{l}-1.486^{* * *} \\
(-9.05)\end{array}$ \\
\hline $\begin{array}{l}D D \times \operatorname{In}\left(\text { Sales }_{i t} / \text { Sales }_{i t-1}\right) \times \\
\text { Fin }\end{array}$ & $\begin{array}{l}0.235^{* *} \\
(2.09)\end{array}$ & $\begin{array}{l}0.236^{* *} \\
(2.06)\end{array}$ & $\begin{array}{l}0.038^{* *} \\
(2.18)\end{array}$ & $\begin{array}{l}0.414^{* *} \\
(1.99)\end{array}$ & $\begin{array}{l}0.371^{* *} \\
(2.04)\end{array}$ & $\begin{array}{l}0.382^{* *} \\
(2.05)\end{array}$ \\
\hline $\begin{array}{l}D D \times \operatorname{In}\left(\text { Sales }_{i t} / \text { Sales }_{i t-1}\right) \times \\
\text { Fin2 }\end{array}$ & - & - & - & $\begin{array}{l}0.173 \\
(0.55)\end{array}$ & - & - \\
\hline 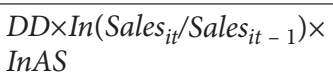 & $\begin{array}{c}-0.113^{* * *} \\
(-7.17)\end{array}$ & $\begin{array}{l}-0.135^{* * *} \\
(-9.19)\end{array}$ & $\begin{array}{c}-0.110^{* * *} \\
(-8.00)\end{array}$ & $\begin{array}{c}-0.112^{* * *} \\
(-8.07)\end{array}$ & $\begin{array}{c}-0.096^{* * *} \\
(-7.06)\end{array}$ & $\begin{array}{c}-0.114^{* \star \star} \\
(-7.54)\end{array}$ \\
\hline 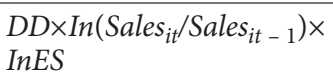 & $\begin{array}{c}-0.111^{* * *} \\
(-9.59)\end{array}$ & $\begin{array}{c}-0.044^{* * *} \\
(-5.13)\end{array}$ & $\begin{array}{l}-0.105^{* * \star} \\
(-10.01)\end{array}$ & $\begin{array}{l}-0.105^{* * *} \\
(-10.02)\end{array}$ & $\begin{array}{c}-0.091^{* * *} \\
(-8.21)\end{array}$ & $\begin{array}{c}-0.111^{* * \star} \\
(-9.65)\end{array}$ \\
\hline $\begin{array}{l}D D \times \operatorname{In}\left(\text { Sales }_{i t} / \text { Sales }_{i t-1}\right) \times \\
G D P\end{array}$ & $\begin{array}{l}0.477 \\
(1.09)\end{array}$ & $\begin{array}{l}0.392^{*} \\
(1.70)\end{array}$ & $\begin{array}{l}0.581 \\
(1.36)\end{array}$ & $\begin{array}{l}0.539 \\
(1.26)\end{array}$ & $\begin{array}{l}0.255 \\
(0.59)\end{array}$ & $\begin{array}{l}0.549 \\
(1.28)\end{array}$ \\
\hline $\begin{array}{l}D D \times \operatorname{In}\left(\text { Sales }_{i t} / \text { Sales }_{i t-1}\right) \times \\
\text { Suc }\end{array}$ & $\begin{array}{c}0.067^{* * \star} \\
(2.95)\end{array}$ & $\begin{array}{l}0.050^{* *} \\
(2.00)\end{array}$ & $\begin{array}{l}0.059^{* * *} \\
(2.87)\end{array}$ & $\begin{array}{c}0.059^{* * *} \\
(2.86)\end{array}$ & $\begin{array}{l}0.042^{*} \\
(1.90)\end{array}$ & $\begin{array}{c}0.066^{* * *} \\
(2.96)\end{array}$ \\
\hline Cons & $\begin{array}{l}0.014^{*} \\
(1.87)\end{array}$ & $\begin{array}{l}0.013^{*} \\
(1.76)\end{array}$ & $\begin{array}{l}-0.001 \\
(-0.01)\end{array}$ & $\begin{array}{l}0.001 \\
(0.02)\end{array}$ & $\begin{array}{l}-0.001 \\
(-0.18)\end{array}$ & $\begin{array}{c}0.018^{* *} \\
(2.47)\end{array}$ \\
\hline Industry/Year & Yes & Yes & Yes & Yes & Yes & Yes \\
\hline Obs & 15624 & 15624 & 18349 & 18349 & 12051 & 18349 \\
\hline $\operatorname{Adj} . R^{2}$ & 0.898 & 0.897 & 0.897 & 0.897 & 0.897 & 0.899 \\
\hline
\end{tabular}

Note: 1$)^{* * *},{ }^{* *},{ }^{\star}$ denote significantly at $1 \%, 5 \%$ and $10 \%$ respectively. 2 ) The values reported in parentheses () indicate $t$ statistics. 


\subsection{Other robustness tests}

In order to examine the robustness of these empirical results, this paper performs several additional tests. Firstly, the paper reconstructs corporate financialization by introducing a dummy variable. If the company purchases the financial assets, the value of dummy variable is 1 , otherwise it is 0 . The regression results are presented in model 6 of Table 4 . The empirical tests show that the coefficient of corporate financialization is 0.038 , which is significantly positive at the $5 \%$ level. As discovered before, there is a weakening relationship between corporate financialization and asymmetric cost behavior.

Secondly, the paper considers the nonlinear relationship between corporate financialization and asymmetric cost behavior by introducing the quadratic term of corporate financialization. The regression results are presented in model 7 of Table 4 . The findings reveal that the coefficient of corporate financialization is 0.414 , which is significantly positive at the $5 \%$ level. Meantime, the quadratic coefficient of corporate financialization is positive but not significant at the $10 \%$ level. The empirical results document that the influence of corporate financialization on asymmetric cost behavior is linear.

Thirdly, the asymmetric cost behavior may be influenced by the corporate culture, the founders' concept and the preference of the executives. In order to eliminate the influence of the company internal factors, this paper selects the panel data of the listed companies in the period of 2009-2017. The results are presented in model 8 of Table 4. The empirical analysis suggests that the coefficient of corporate financialization is 0.371 , which is significantly positive at the $5 \%$ level. Therefore, this paper can confirm that corporate financialization can weaken asymmetric cost behavior.

Finally, the paper selects the sample data of Chinese listed companies over 2010-2017 so as to further avoid the lagged impact of Financial Subprime Mortgage Crisis on the Chinese stock market. The results are presented in model 9 of Table 4 . The regression results show that the coefficient of corporate financialization is 0.382 , which is significantly positive at the $5 \%$ level. This shows that the corporate financialization can relieve the asymmetric cost behavior.

The above results show that the previous findings remain stable after several robustness tests. Overall, the conclusions of this paper is that the corporate financialization can help to weaken the asymmetric cost behavior of enterprises.

\section{Heterogeneous impacts analysis}

A natural question is that how could corporate financialization affect the asymmetric cost behavior. Therefore, the mechanisms for how corporate financialization affects the behavior of asymmetric cost should be investigated. In order to open the black box of how the corporate financialization affects the asymmetric cost behavior, three moderator variables (internal control, compensation incentive and agency problem) are introduced to explore the heterogeneous impacts in the process where the corporate financialization affects the asymmetric cost behavior.

To test hypothesis 2, this paper measures whether there are defects in the internal evaluation report as a proxy variable of good or poor internal control quality (Hunziker, 
2017; Buslepp et al., 2019). When the internal control is not defective, the internal control system of enterprises is relatively good, the value of internal control is 1 , otherwise it is 0 . Columns 2 and 3 of Table 5 describe the heterogeneous impacts of internal control quality. The coefficients of corporate financialization with good and poor internal control quality are 0.538 and 0.326 respectively. The former is significant at the $5 \%$ level. However, the latter is not significant at the $10 \%$ level. This indicates that the weakening effect of corporate financialization on asymmetric cost behavior is mainly reflected in firms with good internal control quality. This supports the $\mathrm{H} 2$.

To test hypothesis 3, the relative managers' compensation which denotes the annual salary ratio that derived from the top-three paid senior administrators (directors, supervisors and executives) divided by the total annual salary of them is adopted to measure the compensation incentive (Sung et al., 2017). The samples are classified according to the median value of the relative managers' compensation. When the relative managers' compensation

Table 5. Heterogeneous impacts results

\begin{tabular}{|c|c|c|c|c|c|c|}
\hline \multirow{2}{*}{ Variable } & \multicolumn{2}{|c|}{$\begin{array}{c}\text { Internal control } \\
\text { quality }\end{array}$} & \multicolumn{2}{|c|}{$\begin{array}{l}\text { Compensation } \\
\text { incentive }\end{array}$} & \multicolumn{2}{|c|}{ Agency problem } \\
\hline & (1)Good & (2)Poor & (1)Strong & (2)Weak & (1)High & (2)Low \\
\hline In $\left(\right.$ Sales $_{i t} /$ Sales $\left._{i t-1}\right)$ & $\begin{array}{l}0.871^{* * *} \\
(111.32)\end{array}$ & $\begin{array}{c}0.871^{* * *} \\
(67.39)\end{array}$ & $\begin{array}{l}0.856^{* * *} \\
(96.04)\end{array}$ & $\begin{array}{l}0.882^{* * *} \\
(106.99)\end{array}$ & $\begin{array}{l}0.767^{* * *} \\
(46.80)\end{array}$ & $\begin{array}{l}0.909^{* * *} \\
(210.3)\end{array}$ \\
\hline$D D \times \operatorname{In}\left(\right.$ Sales $_{i t} /$ Sales $\left._{i t-1}\right)$ & $\begin{array}{c}-1.642^{* * *} \\
(-7.85)\end{array}$ & $\begin{array}{c}-1.570^{* * *} \\
(-6.35)\end{array}$ & $\begin{array}{c}-1.322^{* * *} \\
(-7.05)\end{array}$ & $\begin{array}{c}-1.552^{* * *} \\
(-6.69)\end{array}$ & $\begin{array}{c}-1.626^{* * *} \\
(-6.10)\end{array}$ & $\begin{array}{l}-0.605^{* * *} \\
(-4.09)\end{array}$ \\
\hline $\begin{array}{l}D D \times I n\left(\text { Sales }_{i t} / \text { Sales }_{i t-1}\right) \times \\
\text { Fin }\end{array}$ & $\begin{array}{l}0.538^{* *} \\
(2.25)\end{array}$ & $\begin{array}{l}0.326 \\
(1.14)\end{array}$ & $\begin{array}{l}0.537^{* *} \\
(2.49)\end{array}$ & $\begin{array}{l}0.362 \\
(1.32)\end{array}$ & $\begin{array}{l}0.292 \\
(1.07)\end{array}$ & $\begin{array}{c}0.603^{* * *} \\
(3.46)\end{array}$ \\
\hline $\begin{array}{l}D D \times I n\left(\text { Sales }_{i t} / \text { Sales }_{i t-1}\right) \times \\
\operatorname{InAS}\end{array}$ & $\begin{array}{c}-0.131^{* * *} \\
(-5.99)\end{array}$ & $\begin{array}{c}-0.081^{* * *} \\
(-4.14)\end{array}$ & $\begin{array}{c}-0.111^{* * *} \\
(-6.13)\end{array}$ & $\begin{array}{c}-0.112^{* * *} \\
(-5.31)\end{array}$ & $\begin{array}{l}-0.155^{* * *} \\
(-5.46)\end{array}$ & $\begin{array}{c}-0.033^{* * *} \\
(-2.81)\end{array}$ \\
\hline $\begin{array}{l}D D \times \operatorname{In}\left(\text { Sales }_{i t} / \text { Sales }_{i t-1}\right) \times \\
\operatorname{InES}\end{array}$ & $\begin{array}{c}-0.124^{* * *} \\
(-8.22)\end{array}$ & $\begin{array}{c}-0.115^{* * *} \\
(-6.84)\end{array}$ & $\begin{array}{c}-0.100^{* * *} \\
(-7.30)\end{array}$ & $\begin{array}{c}-0.117^{* * *} \\
(-7.44)\end{array}$ & $\begin{array}{c}-0.138^{* * *} \\
(-6.83)\end{array}$ & $\begin{array}{c}-0.041^{* * *} \\
(-4.20)\end{array}$ \\
\hline $\begin{array}{l}D D \times I n\left(\text { Sales }_{i t} / \text { Sales }_{i t-1}\right) \times \\
G D P\end{array}$ & $\begin{array}{l}0.706 \\
(1.15)\end{array}$ & $\begin{array}{l}0.241 \\
(0.33)\end{array}$ & $\begin{array}{l}0.496 \\
(0.86)\end{array}$ & $\begin{array}{l}0.463 \\
(0.74)\end{array}$ & $\begin{array}{l}0.130 \\
(0.19)\end{array}$ & $\begin{array}{l}0.519 \\
(1.24)\end{array}$ \\
\hline $\begin{array}{l}\text { DD } \times \operatorname{In}\left(\text { Sales }_{i t} / \text { Sales }_{i t-1}\right) \times \\
\text { Suc }\end{array}$ & $\begin{array}{l}0.052^{*} \\
(1.88)\end{array}$ & $\begin{array}{l}0.075^{* *} \\
(2.12)\end{array}$ & $\begin{array}{c}0.091^{* * *} \\
(3.33)\end{array}$ & $\begin{array}{l}0.008 \\
(0.27)\end{array}$ & $\begin{array}{c}0.087^{* * *} \\
(2.83)\end{array}$ & $\begin{array}{c}0.057^{* * *} \\
(3.12)\end{array}$ \\
\hline Cons & $\begin{array}{l}-0.013 \\
(-1.39)\end{array}$ & $\begin{array}{l}-0.003 \\
(-0.13)\end{array}$ & $\begin{array}{l}-0.007 \\
(-0.58)\end{array}$ & $\begin{array}{l}0.007 \\
(1.03)\end{array}$ & $\begin{array}{l}-0.014 \\
(-0.97)\end{array}$ & $\begin{array}{l}0.004 \\
(0.56)\end{array}$ \\
\hline Industry/Year & Yes & Yes & Yes & Yes & Yes & Yes \\
\hline Obs & 11830 & 4301 & 9185 & 9164 & 6397 & 11952 \\
\hline $\operatorname{Adj} . R^{2}$ & 0.899 & 0.895 & 0.892 & 0.906 & 0.823 & 0.943 \\
\hline
\end{tabular}

Note: 1$)^{* * *},{ }^{* *},{ }^{*}$ denote significantly at $1 \%, 5 \%$ and $10 \%$ respectively. 2 ) The values reported in parentheses () indicate t statistics. 
is greater than the median, the value is 1 , otherwise it is 0 . The heterogeneous impacts of compensation incentive are presented in column 4 and 5 of Table 5 . The coefficients of corporate financialization with strong and weak compensation incentives are 0.537 and 0.362 respectively. The former is significant at the $5 \%$ level. Meanwhile, the latter is not significant at the $10 \%$ level. The above results reveal that the weakening effect of corporate financialization to asymmetric cost behavior is mainly reflected in firms with stronger compensation incentive. This supports the $\mathrm{H} 3$.

To test hypothesis 4 , the ratio of managerial expenses which refers to managerial expenses of the enterprise divided by sales revenue is applied to measure the managers' agency problem (Ang et al., 2000). A high ratio of managerial expenses represents that the company's profits are being consumed too much on the organizational and administrative activities. It implies that agency costs are high. Accordingly, when the ratio of managerial expenses is greater than the average value, the value is 1 , or it is 0 . The heterogeneous impacts of agency problem are illustrated in column 6 and 7 of Table 5. The coefficients of corporate financialization with high and low agency problems are 0.292 and 0.603 respectively. The former is not significant at the $10 \%$ level. Meanwhile, the latter is significant at the $1 \%$ level. This results show that the weakening effect of corporate financialization on asymmetric cost behavior is mainly reflected in firms with the low agency problem. This supports the H4.

\section{Conclusions}

This paper studies the direct influence and heterogeneous impacts of corporate financialization on asymmetric cost behavior. The research finds that corporate financialization significantly weakens the asymmetric cost behavior. Quantile regression, endogeneity tests and other robustness checks show that corporate financialization can indeed significantly reduce the asymmetric cost behavior. Further studies show that the influence of corporate financialization on asymmetric cost behavior is mainly manifested in firms with good internal control quality, strong compensation incentive and low agency problem. On the contrary, the weakening effect is insignificant in firms with poor internal control quality, weak compensation incentive and high agency problem.

The conclusions of this paper are of strong practical guiding significance for the shareholders' governance of listed companies and government to establish the micro-financial policies. In the background of the low-speed development of domestic economy, the government maintains an open attitude towards the corporate financialization, which not only helps to ease the financing difficulties of some enterprises through purchasing financial assets between enterprises, but also helps to reduce the asymmetric cost behavior through investing slack cash on the financial assets. However, excessive financialization will also bring some negative effects. Therefore, this paper suggests that the enterprises should hold financial assets in moderation.

Note that the weakening influence of corporate financialization on asymmetric cost behavior is not applicable for all the enterprises. An enterprise with weaker corporate governance (poor internal control quality, weak compensation incentive and high agency problem) should improve corporate governance to further optimize the management of asymmetric cost behavior. 
Still, there are some shortcomings in this paper. First, the time range of the sample is from 2009 to 2017. If corporate financialization is one of the most important determinants of asymmetric cost behavior, the conclusions of this paper are supposed to hold outside the sample period. However, this is not discussed in this paper. Second, although the empirical results show that corporate financialization has a weakening effect on asymmetric cost behavior, this paper didn't examine whether the influence exists in enterprises with different natures and life cycles. This is left for future studies.

\section{Acknowledgements}

We appreciate the comments and suggestions from two reviewers and the effort made by editors.

\section{Funding}

This work was supported by the National Natural Science Foundation of China (71702203; 71971169) and Special Program from Shaanxi Province Philosophy Social Science Leading Talent.

\section{Author contributions}

Guanping Zhu conceived the study, collected the data and wrote the manuscript. Guanping Zhu, Wenxiu $\mathrm{Hu}$ and Chaokai Xue were responsible for data analysis and discussion of the manuscript. Tao Peng was responsible for the interpretation of the obtained results, the discussion of the results and contributed to the final manuscript. All authors agreed the final version.

\section{Disclosure statement}

The authors of this paper declare that there are no competing financial, professional, or personal interests from other parties.

\section{References}

Akerlof, G. A. (1978). The market for "lemons": Qualitative uncertainty and the market mechanism. In P. Diamond \& M. Rothschild (Eds.), Uncertainty in economics (pp. 235-251). Elsevier. https://doi.org/10.1016/B978-0-12-214850-7.50022-X

Akkemik, K. A., \& Ozen, S. (2014). Macroeconomic and institutional determinants of financialisation of non-financial firms: Case study of Turkey. Socio-Economic Review, 12(1), 71-98. https://doi.org/10.1093/ser/mwt006

Aktas, N., Andreou, P. C., Karasamani, I., \& Philip, D. (2019). CEO duality, agency costs, and internal capital allocation efficiency. British Journal of Management, 30(2), 473-493. https://doi.org/10.1111/1467-8551.12277

Anderson, M. C., Banker, R. D., \& Janakiraman, S. N. (2003). Are selling, general, and administrative costs "sticky"? Journal of Accounting Research, 41(1), 47-63. https://doi.org/10.1111/1475-679X.00095 
Ang, J. S., Cole, R. A., \& Lin, J. W. (2000). Agency costs and ownership structure. The Journal of Finance, 55(1), 81-106. https://doi.org/10.1111/0022-1082.00201

Balakrishnan, R., Labro, E., \& Soderstrom, N. S. (2014). Cost structure and sticky costs. Journal of Management Accounting Research, 26(2), 91-116. https://doi.org/10.2308/jmar-50831

Banker, R. D., \& Byzalov, D. (2014). Asymmetric cost behavior. Journal of Management Accounting Research, 26(2), 43-79. https://doi.org/10.2308/jmar-50846

Banker, R. D., Byzalov, D., \& Chen, L. (2013). Employment protection legislation, adjustment costs and cross-country differences in cost behavior. Journal of Accounting and Economics, 55(1), 111-127. https://doi.org/10.1016/j.jacceco.2012.08.003

Bugeja, M., Lu, M., \& Shan, Y. (2015). Cost stickiness in Australia: Characteristics and determinants. Australian Accounting Review, 25(3), 248-261. https://doi.org/10.1111/auar.12066

Buslepp, W., Legoria, J., Rosa, R., \& Shaw, D. (2019). Misclassification of audit-related fees as a measure of internal control quality. Advances in Accounting, 46, 1-10. https://doi.org/10.1016/j.adiac.2019.100425

Calleja, K., Steliaros, M., \& Thomas, D. C. (2006). A note on cost stickiness: Some international comparisons. Management Accounting Research, 17(2), 127-140. https://doi.org/10.1016/j.mar.2006.02.001

Cannon, J. N. (2014). Determinants of "sticky costs": An analysis of cost behavior using United States air transportation industry data. The Accounting Review, 89(5), 1645-1672. https://doi.org/10.2308/accr-50806

Chen, H. W., Liao, F. N., \& Han, H. L. (2019). The governance effect of independent director connection and internal control on earnings management. China Business Management Journal, 41(5), 171-191. https://doi.org/10.19616/j.cnki.bmj.2019.05.011

Chen, C. X., Lu, H., \& Sougiannis, T. (2012). The agency problem, corporate governance, and the asymmetrical behavior of selling, general, and administrative costs. Contemporary Accounting Research, 29(1), 252-282. https://doi.org/10.1111/j.1911-3846.2011.01094.x

Cheng, Q., Goh, B. W., \& Kim, J. B. (2018). Internal control and operational efficiency. Contemporary Accounting Research, 35(2), 1102-1139. https://doi.org/10.1111/1911-3846.12409

Datta, S., Mello, R., \& Iskandar-Datta, M. (2009). Executive compensation and internal capital market efficiency. Journal of Financial Intermediation, 18(2), 242-258. https://doi.org/10.1016/j.jfi.2008.04.001

Demir, F. (2009). Financial liberalization, private investment and portfolio choice: Financialization of real sectors in emerging markets. Journal of Development Economics, 88(2), 314-324. https://doi.org/10.1016/j.jdeveco.2008.04.002

Du, Y., Zhang, H., \& Chen, J. Y. (2017). The impact of financialization on the future development of the main business of real enterprises: promote or inhibit. China Industrial Economics, 12, 113-131.

Duchin, R., Gilbert, T., Harford, J., \& Hrdlicka, C. (2017). Precautionary savings with risky assets: When cash is not cash. The Journal of Finance, 72(2), 793-852. https://doi.org/10.1111/jofi.12490

Froud, J., Haslam, C., Johal, S., \& Williams, K. (2000). Shareholder value and financialization: Consultancy promises, management moves. Economy and Society, 29(1), 80-110. https://doi.org/10.1080/030851400360578

Gehringer, A. (2013). Growth, productivity and capital accumulation: The effects of financial liberalization in the case of European integration. International Review of Economics \& Finance, 25, 291-309. https://doi.org/10.1016/j.iref.2012.07.015

Guenther, T. W., Riehl, A., \& Rößler, R. (2014). Cost stickiness: State of the art of research and implications. Journal of Management Control, 24(4), 301-318. https://doi.org/10.1007/s00187-013-0176-0

Habib, A., \& Hasan, M. M. (2019). Corporate social responsibility and cost stickiness. Business \& Society, 58(3), 453-492. https://doi.org/10.1177/0007650316677936 
Hadi, A., Diantimala, Y., \& Fahlevi, H. (2018). The effect of preventive supervision, detective supervision on the effectiveness of financial budget control and its impact on good governance of Aceh government (Study on Aceh government unit). International Journal of Academic Research in Business and Social Sciences, 8(5), 707-715. https://doi.org/10.6007/IJARBSS/v8-i5/4171

Haga, J., Höglund, H., \& Sundvik, D. (2019). Cost behavior around corporate tax rate cuts. Journal of International Accounting, Auditing and Taxation, 34, 1-11. https://doi.org/10.1016/j.intaccaudtax.2019.01.001

Hartlieb, S., Loy, T. R., \& Eierle, B. (2020). Does community social capital affect asymmetric cost behavior? Management Accounting Research, 46, 1-15. https://doi.org/10.1016/j.mar.2019.02.002

Heidari, M. (2014). Examining managerial overconfidence behavioral explanation effect on cost stickiness: Comparison with economic and agency theory based factors. Journal of Accounting and Auditing Review, 21(2).

Holmstrom, B. (1979). Moral hazard and observability. Bell Journal of Economics, 10(1), 74-91. https://doi.org/10.2307/3003320

Hou, Q. M., Song, L., \& Jiang, Y. P. (2017). Managerial behavior, corporate life cycle and non-efficiency investment. China Accounting Research, (3), 61-67+95.

Huang, X. H., Wu, Q. S., \& Wang, Y. (2018). Financial asset allocation and corporate financial risks: "Prepare for a rainy day" or "Care for the end". China Journal of Finance and Economics, 44(12), 100-112+125. https://doi.org/10.16538/j.cnki.jfe.2018.12.008

Hunziker, S. (2017). Efficiency of internal control: Evidence from Swiss non-financial companies. Journal of Management \& Governance, 21(2), 399-433. https://doi.org/10.1007/s10997-016-9349-1

Jensen, M. C. (1986). Agency costs of free cash flow, corporate finance, and takeovers. The American Economic Review, 76(2), 323-329. https://www.jstor.org/stable/1818789

Jensen, M. C., \& Meckling, W. H. (1976). Theory of the firm: Managerial behavior, agency costs and ownership structure. Journal of Financial Economics, 3(4), 305-360. https://doi.org/10.1016/0304-405X(76)90026-X

Jensen, M. C., \& Murphy, K. J. (1990). Performance pay and top-management incentives. Journal of Political Economy, 98(2), 225-264. https://doi.org/10.1086/261677

Jiang, W., Hu, Y. M., \& Zeng, Y. Q. Z. (2015). Financial constraints and cost stickiness: Evidence from Chinese industrial firms. China Financial Research, 10, 133-147.

Kama, I., \& Weiss, D. (2013). Do earnings targets and managerial incentives affect sticky costs? Journal of Accounting Research, 51(1), 201-224. https://doi.org/10.1111/j.1475-679X.2012.00471.x

Kim, J. B., Lee, J. J., \& Park, J. C. (2019). Internal control weakness and the asymmetrical behavior of selling, general, and administrative costs. Journal of Accounting, Auditing \& Finance, 2, 1-34. https://doi.org/10.1177/0148558X19868114

Krause, R., Semadeni, M., \& Cannella, Jr. A. A. (2014). CEO duality: A review and research agenda. Journal of Management, 40(1), 256-286. https://doi.org/10.1177/0149206313503013

Lee, W. J., Pittman, J., \& Saffar, W. (2020). Political uncertainty and cost stickiness: Evidence from national elections around the world. Contemporary Accounting Research, 37(2), 1107-1139. https://doi.org/10.1111/1911-3846.12547

Li, S. H., Jiang, X. F., \& Song, X. Z. (2015). Senior manager's age and salary incentive: Theoretical path and empirical evidence. China Industrial Economics, (5), 122-134. https://doi.org/10.19581/j.cnki.ciejournal.2015.05.011

Morse, A., Nanda, V., \& Seru, A. (2011). Are incentive contracts rigged by powerful CEOs? The Journal of Finance, 66(5), 1779-1821. https://doi.org/10.1111/j.1540-6261.2011.01687.x

Noreen, E. (1991). Conditions under which activity-based cost systems provide relevant costs. Journal of Management Accounting Research, 3(4), 159-168. 
Orhangazi, Ö. (2008). Financialisation and capital accumulation in the non-financial corporate sector: A theoretical and empirical investigation on the US economy: 1973-2003. Cambridge Journal of Economics, 32(6), 863-886. https://doi.org/10.1093/cje/ben009

Park, Y. J., Matkin, D. S., \& Marlowe, J. (2017). Internal control deficiencies and municipal borrowing costs. Public Budgeting \& Finance, 37(1), 88-111. https://doi.org/10.1111/pbaf.12120

Peng, Y. C., Ni, X. R., \& Shen, J. (2018). The effect of transforming the economy from substantial to fictitious financial market stability: An analysis on stock price crash risk. China Economic Research Journal, 53(10), 50-66.

Prabowo, R., Hooghiemstra, R., \& Van Veen-Dirks, P. (2018). State ownership, socio-political factors, and labor cost stickiness. European Accounting Review, 27(4), 771-796. https://doi.org/10.1080/09638180.2017.1329659

Priantana, R. D., Rohman, A., \& Fuad. (2020). Attainment discrepancy level, firm resources slack, and sticky cost. International Journal of Financial Research, 11(2), 97-110. https://doi.org/10.5430/ijfr.v11n2p97

Salehi, M., Ziba, N., \& Daemi Gah, A. (2018). The relationship between cost stickiness and financial reporting quality in Tehran Stock Exchange. International Journal of Productivity and Performance Management, 67(9), 1550-1565. https://doi.org/10.1108/IJPPM-10-2017-0255

Seo, H. J., Kim, H. S., \& Kim, Y. C. (2012). Financialization and the slowdown in Korean firms' R\&D investment. Asian Economic Papers, 11(3), 35-49. https://doi.org/10.1162/ASEP_a_00160

Shin, H. S., \& Zhao, L. (2013). Firms as surrogate intermediaries: Evidence from emerging economies. Asian Development Bank, 1-44.

Steinbach, A. L., Holcomb, T. R., Holmes, Jr. R. M., Devers, C. E., \& Cannella, Jr. A. A. (2017). Top management team incentive heterogeneity, strategic investment behavior, and performance: A contingency theory of incentive alignment. Strategic Management Journal, 38(8), 1701-1720. https://doi.org/10.1002/smj.2628

Sung, S. Y., Choi, J. N., \& Kang, S. C. (2017). Incentive pay and firm performance: Moderating roles of procedural justice climate and environmental turbulence. Human Resource Management, 56(2), 287-305. https://doi.org/10.1002/hrm.21765

Theurillat, T., Corpataux, J., \& Crevoisier, O. (2010). Property sector financialization: The case of Swiss pension funds (1992-2005). European Planning Studies, 18(2), 189-212. https://doi.org/10.1080/09654310903491507

Tori, D., \& Onaran, O. (2018). The effects of financialisation on investment: Evidence from firm-level data in UK. Cambridge Journal of Economics, 42(5), 1393-1416. https://doi.org/10.1093/cje/bex085

Venieris, G., Naoum, V. C., \& Vlismas, O. (2015). Organisation capital and sticky behaviour of selling, general and administrative expenses. Management Accounting Research, 26, 54-82. https://doi.org/10.1016/j.mar.2014.10.003

Xie, B., Davidson III, W. N., \& DaDalt, P. J. (2003). Earnings management and corporate governance: The role of the board and the audit committee. Journal of Corporate Finance, 9(3), 295-316. https://doi.org/10.1016/S0929-1199(02)00006-8

Zhang, M P., \& Sun, Y Q. (2014). The allocation efficiency of financial resources and the causes of economic financialization - Based on the empirical analysis of Chinese listed companies. China Economist, (4), 81-90. https://doi.org/10.16158/j.cnki.51-1312/f.2014.04.012

Zhou, B., Zhong, T. Y., Xu, H., \& Ren, Z. L. (2016). Corporate strategy, management expectation and cost stickiness: Based on empirical data of China's listed companies. China Accounting Research, (7), 58-65+97. 